down, not however without having still violently roared in the evening and night of August 27 to 28. The detonations were scarcely less strong at Buitenzorg from ten to one o'clock than in the morning. But after the 28th nothing more was heard of the mountain. The tidal registrations at Tandjong Priok exhibit still a few small oscillations till August 30 at twelve o'clock in the day, but after that the condition of the water also became normal. Notwithstanding this I found that there must have been a serious eruption a considerable time after August 28, and shortly before I visited the island.

On October I I I left Batavia with my staff, and after having visited various points in the Straits of Sunda, arrived at Calmeyer on the 15 th. We stopped a few hours in order to survey the island, which is a perfectly bare bank of pumicestone, divided into seven parts by encroachments of the sea ; the temperature was $42^{\circ}$ Celsius, a heat which almost stupefied us. Here already my attention was drawn to the fact that the white or pale gray pumice-sand was covered by a 0.2 metre thick layer of darker coloured very fine ash, which exhibited numerous fissures on the surface, produced in the process of drying, and therefore had probably fallen there as wet mud. I did not, however, then attach any special importance to this phenomenon.

On the ${ }^{6} \mathrm{fth} I$ arrived at Krakatoa and remained there till the 18 th. When in surveying the mountain on the I 7 th we had climbed to the top, and began the steep descent on the south side, I observed with astonishment that on the ordinary gray pumice-stone material two black streaks were visible, which began 600 metres above the sea, therefore about 200 metres lower than the top, and could be traced in a tolerably straight line over a length of 1300 metres till 100 metres above the sea. These black streaks proved to be two mud streams, which had flowed down the slope of the mountain and had covered the white pumice-stone to the thickness on an average of 0.2 to 0.3 metre and a breadth of $I$ to 5 metres. The most remarkable fact was, however, that these mud streams were not only traced down the back of the mountain but had also flowed into the deep ravines of pumice-stone material, as can be distinctly seen. Therefore those mud streams did not arrive there till the crevices in the pumice-sand already existed, and as several weeks must have been required for the water to hollow out these ravines the mud eruption cannot immediately have followed the eruptions of August. The very fine dark gray mud was still damp at the time of my visit, and could be kneaded with the hand, which also proves that the streams were of recent origin.

In this eruption very curious objects were ejected, i.e. very smooth, round balls resembling marbles, to the size of $I_{2}^{\frac{1}{2}}$ to 6 centimetres in diameter. They are full of acids, they contain 55 per cent. carbonate of lime, 26 per cent. silica, i i per cent. alumina, and 5 per cent. water. These calcareous lumps of marl must be derived from layers of marl which exist at the bottom of the Straits of Sunda in the neighbourhood of Krakatoa, and the slime or dust of which has been shot out of the crater in a rapid revolving motion. The balls, which are rare, are never found inside but only on the top of the pumice-stone dust, generally half sunk in the sand; they evidently belong to the last ejections. Whether the mud streams also contain lime I have not been able to ascertain, as a piece brought as a sample has unfortunately been lost.

The last mud eruption, which must have been very important, since on Calmeyer, I 2 kilometres from Krakatoa the upper black layer is 0.2 metre thick, and the mud must have been thrown over the top, which is 830 metres high, to the back of the mountain, whence it poured down, probably took place only six days before my arrival, namely on October Io, at about $9 \mathrm{~h}$. $30 \mathrm{~m}$. in the evening, because on that evening at about ten o'clock a considerable tide wave arrived at Tjikawoeng in Welkomstbaai
(Welcome Bay), the only tide wave which was observed since August 28. A rumbling sound in the direction of Krakatoa was then heard in that place, as well as a little more northward at Soemoer. The wave overflowed the shore to a distance of 75 metres beyond the tide-mark at Tjikawoeng, but has not been observed at other points of the coast, as the devastated coast country was not yet inhabited and was quite abandoned at night. We find in this another proof that the falling down of large quantities of ejected substances round Krakatoa suffices to form important waves in the Straits of Sunda.

The eruption on October Io seems to have been the last. But this eruption was scarcely noticed, and it is therefore possible that subsequent feebler volcanic actions may have remained quite unobserved. When I visited Krakatoa there was nowhere any sign of activity. On October I 8 we left Krakatoa, and we arrived on the evening of the Igth at Vlakken Hoek, where nothing was noticcable. It is not likely, therefore, that the rumbling sounds which were heard that evening at Tangerang and Mauk coming from the west should have proceeded from Krakatoa. It would, however, be very interesting to visit Krakatoa once more in order to be able to trace whether any more changes have taien place since October i 8 .

Though there is no fear of any serious eruption of Krakatoa after the terrific activity of the volcano and the subsidence of the greater part of the island, still much that is intcresting may be learnt yet from less important subsequent volcanic actions, as we see in the instance of the lumps of marl.

With the detailed report a large map of Krakatoa will appear, as well as maps of Calmeyer, the devastated parts of Merak, Java's First Point, Sebesi, Seboekoe, Telok Betong, and Kalianda; moreover tables indicating the pressure at the gas-works at Batavia, and of the selfregistering tidal apparatus at Tandjong Priok and at Soerabaja; a small "ash map" and other supplements, and finally a few coloured drawings of Krakatoa and the devastated districts, where in a few moments tens of thousands of people lost their lives on the memorable 27 th of August, I883.

Buitenzorg, February 19, 1884

\section{THE LATE MONSIEUR DUMAS}

$A \mathrm{~T}$ the funeral of this eminent chemist addresses were given by the representatives of various official bodies. From these we subjoin the following extracts, affording as they do an idea of the estimation in which $M$. Dumas was held by his contemporaries, and of the position to which he is entitled in the science of the present century.

M. le Comte d'Haussonville, Director of the French Academy, said :-

"Who was more worthy than Jean Baptiste Dumas of the high distinctions conferred on him by the Academy of Sciences! By us he was welcomed at a time when his name already ranked amongst the most illustrious of our times, when he had already been hailed as a master by associates destined soon to become masters in their turn. To their authoritative voice, rather than to me, must belong the duty of recording the signal services rendered to science by our regretted colleague, whose mortal remains lie at our feet. They will tell you with a fulness far beyond my power how, under the first inspiration of his soul, he understood how to vary his experiments and verify his assumptions. And with what supreme delight, says one of our confrères, who had the honour to receive him into the Academy, he pierced with eagle-eye into the depths of the divine laboratory, beyond which there is naught but the infinite, the unfathomable, the unapproachable! Speaking of his own work, he himself thus expresses himself :--'Above the sphere of phenomena which we study, and where such a vast field of discovery still 
lies open before us, there is still a higher sphere inaccessible to our methods. We begin to understand the life of bodies; that of the soul belongs to another order.' My years, near enough to those of the venerable seer by whose death we are overwhelmed with grief, enabled me to assist at one of M. Dumas' earliest triumphs. It was before the year 1848 , when in his official capacity he ascended the tribune of the House of Deputies in order to expound the whole mechanism of minting in connection with a law then under discussion. Notwithstanding the dryness of the subject, I still remember how we remained for two hours captivated by the charm of his natural eloquence. In taking leave of so great a memory, permit me to repeat the glowing words recently uttered by $M$. Dumas himself on the occasion of the death of his distinguished colleague, M. Regnault: 'The Academy, faithful interpreter of posterity and sole heir of your renown, hastens to render a public homage of affection to your person, of thanks for the great and noble work of your life, of respect for your brilliant services, awaiting the time when science and your country shall pay their debt to a name worthy of every honour.'"

M. J. Bertrand, Perpetual Secretary of the Academy of Sciences, said :-

"M. Dumas has been our universal teacher. His lectures at the Athenæum, at the College of France, at the Central School, at the School of Medicine, the Faculty of Sciences, and Polytechnic, had so many attractions, he understood so well how to inspire his audience, he indicated the path of progress so clearly, and made each discourse so finished and perfect in itself, that all alike withwithdrew resolved not to miss the following lecture.

"In the history of reformed chemistry no name will assuredly eclipse that of M. Dumas. Eager to disseminate his ideas, skilful in placing his proofs in a clear light, his wise and lofty intellect surveyed from a high standpoint the main routes of science, acting cver as a faithful guide to all who, younger than himself, considered that they honoured themselves in proclaiming him their master."

M. Rolland, as President of the Academy of Sciences, naturally entered into some detail on the scientific work of M. Dumas. Among other things he said :-

"The scientific work of J. B. Dumas is immense, and his labours have long shed a lustre on his name. In his thirty-second year he had already joined the Academy of Sciences, of which he subsequently became one of the most eminent and respected members. I cannot attempt here to mention all the numerous discoveries due to his genius, by which he has so potently contributed to the establishment of modern chemistry, herein showing himself the worthy successor of Lavoisier.

"I will therefore restrict my remarks to the second period of his career, during which, as Perpetual Secretary of the Academy of Sciences, he enabled us better to appreciate his subtle and lofty intellect, his profound knowledge of men and things. Hence his authority was unanimously recognised by his colleagues, whose councils and labours were so often controlled by him with admirable tact and prudence under peculiarly delicate circumstances. If to these rare gifts be added a fluent speech, a kindly and sympathetic feeling from which he never departed, it will be understood how highly prized was the combination of these exceptional qualities, how valued by the Academy, where Dumas so often played the part of guide and director.

"These eminent virtues had long been esteemed and utilised by other societies also, such as those of the Central School, of the Friends of Science, and others, over whose labours he had presided for many years. He was also intrusted with the presidency of several international Commissions, where were discussed many important questions in connection with a uniform system of weights, measures, and currency, as well as with the determination of electric units. There might perhaps be reason rather to regret the manifold occupations and public duties which absorbed so much of his time, diverting him from the prosecution of purely scientific researches, where so much might still be hoped from such a powerful genius. For, in spite of a long life devoted to incessant work, our confrère had to the last preserved his strong intellect and mental activity.

"But however great and varied were the labours constantly claiming his attention, he never neglected his more personal duties. His was the life of a true patriarch, ever encircled by his children and children's children, who cherished his fair name and ever rejoiced in the constant solicitude of a tender and devoted father.

"Dumas had married the daughter of Alexander Brongniart in the year 1825. All who, like myself, had the privilege to be welcomed in that happy circle, can testify to the intimate and devoted character of their union down to these last days. I may here be permitted to express to the bereaved widow our warmest sympathy in the loss which to-day deprives her of the affectionate support of such a well-beloved husband.

"But the time has come to bid a last farewell to the mortal spoils of our illustrious colleague, whose memory shall ever remain engraved on our hearts, whose name is eternally enrolled amongst those of the great thinkers by whom the nineteenth century has been most honoured."

Following M. Rolland came M. Wurtz, who spoke on behalf of the Faculties of Science and Medicine.

"To those already deposed on the remains of $M$. Dumas, the University," M. Wurtz said, "adds other wreaths in supreme homage to the teacher by whom we have all profited, to the santant who has shed a lustre on our times, to the worthy citizen who has left a void in the hearts of all. Ours is a public mourning, and above the voices which we hear around us I seem to hear the great voice of France, which in Dumas suffers an irreparable loss. For a period of sixty years he served her with distinction under the most varied circumstances.

"To a piercing genius, an intuition leading to great discoveries and broad views of the universe, Dumas added the choicest gifts of eloquence, of a clear and graceful style, gifts which make the orator and the writer. $\mathrm{He}$ was the ideal of a French savant, and history will award him a place not far removed from that of his admired master, Lavoisier.

"Born at Alais in I 800 , he began life as a chemist's assistant in Geneva. But he was scarcely twenty years of age when, jointly with Prévost, he published some researches on various physiological subjects, and notably some experiments on the blood, which have held their ground to the present time. After his arrival in Paris in I 82 I he devoted himself exclusively to chemistry, and soon felt himself competent to undertake such grave work as the independent development of organic chemistry, and the reform of mineral chemistry. And if during the last fifty years chemistry has broken new ground, and become, so to say, transformed under our eyes, this has been accomplished in virtue of a programme he was the first to trace, and the foundations of which were laid by his own discoveries. The ideas at that time current had been drawn from the relatively simple study of mineral compounds. All combinations, it was assumed, are formed of two direct elements, themselves either simple bodies or compounds in the first degree. This so-called 'dualism' in chemistry, traceable to Lavoisier, had been adopted and developed by Berzelius, but was overthrown by Dumas. Studying in 1834 the action of chlorine on organic compounds, he detected in this simple body 'the remarkable power of replacing hydrogen atom by atom.' Such was the first announcement of a law which, supported by thousands of analogous cases, now forms the point of departure for the theory of substitutions and its consequences, associated with the neme of Dumas. This 
conception was developed in a series of memoirs dealing with chemical types, and was later on generalised and simplified by Charles Gerhardt.

“Dumas' studies embraced every branch of the science-discovery and description of mineral and organic compounds, analysis of numerous substances and improvement of the methods of analysis themselves, determination of atomic weights. With the penetration of inventive genius he introduced into all his researches that firm grasp of the subject, that accuracy in details, that critical spirit which are the essential conditions and necessary instruments of all scientific investigation.

"And how shall I speak of his theoretical views expressed on a great variety of special subjects, and embodied either in his great 'Traité de Chimie Appliquée aux Arts,' or in his admirable 'Leçons de Philosophie Chimique'? Merely to mention one point, to Dumas we are indebted for a first attempt at a classification of simple nonmetallic bodies, an attempt which has still its value.

"Let me also remind you that, after enriching physiological chemistry at the outset of his carcer, he soon after endowed physics with a new method for determining the densities of vapour, in continuation of the work begun by his master, Gay-Lussac.

"But a complete idea of his influence and authority cannot be had without reference to his career as a teacher. On his arrival in Paris he opens a course of lectures at the Athenæum. Later on he founds, jointly with Lavallée, Ollivier, and Péclet, the Central School of Arts and Manufactures, where he conducts the chemical class for a quarter of a century. In 1832 he replaces Thenard at the Polytechnic, and the same year is appointed Assistant Professor to the Faculty of Sciences. In 184I he becomes at once Titulary and Dean of the same Faculty, having three years previously obtained the Chair of Organic Chemistry in the Faculty of Medicine. It was here perhaps that his talents as a teacher achieved their greatest triumphs. $\mathrm{He}$ was at that time at the most brilliant period of his creative genius, and he set forth the great ideas then animating him with sympathetic warmth and persuasion, with inimitable clearness and wealth of illustration.

"Such, in a few words, has been the preponderating part played by $M$. Dumas in science and instruction. And although during his last years he withdrew from public life, it was only to devote himself to work of another order. He was equal to every undertaking imposed on him, the soul of the many committees over which he presided, the ornament of the Academic celebrations which he honoured by his presence and addresses. And after such a long and glorious life what remained except a peaceful end in the midst of his family circle, and in the full enjoyment of all his faculties? But such a commanding figure cannot pass into forgetfulness. Your memory, Dumas, shall be perpetuated, your name transmitted from age to age. You shall live in your works, in the example you have given, in the immortal productions and rare qualities of your mind : Forma mentis ceterna."

\section{THE EARTHQUAKE}

FARTHQUAKES are so rarely observed in England, that an exceptional interest attaches to that of April 22, an interest far in excess of that due to its intrinsic importance. Fortunately the earthquake is exceptional in another sense. It is seldom that a shock results in so small a loss of human life in proportion to the damage done to houses.

The daily London press, for a few days after the occurrence, gave much information as to the range of the earthquake, and the nature and amount of the damage done ; further details are given in the local papers of the Eastern Counties, but we are still sadly in want of definite statements upon many matters of great importance. In this article we shall notice only a few points of interest, reserving for a later issue, it is hoped by the aid of fuller knowledge, a more complete account of the phenomena, to be illustrated by a map showing the area of disturbance.

The shock was most severely felt near the north shore of the estuary of the Blackwater, and for about six miles inland to the north, in the direction of Colchester. The geology of this district is simple. Nearly all the country is occupied by London Clay; over the marshy land of the Colne, and the flats separating Mersea Island from the mainland, there is a covering of recent alluvial deposits ; over parts of the higher land of Mersea Island there are patches, from a quarter of a square mile to one square mile in area, of Glacial gravel, the remnants of a great sheet of similar material which once overspread the London Clay and joined the large area of similar gravel near Colchester. This town is mostly built on gravel, which rises to a greater height, and occurs in considerable thickness, to the south-west of the town--over Lexden and Stanway Heaths ; further to the west and south-west this gravel passes under Boulder Clay. Underlying the whole of the Tertiary beds of the east of England there is a continuous bed of Chalk, from 600 to 1000 or more feet in thickness. Below the Chalk there is a bed of Gault Clay of varying thickness. But here our certain knowledge of the geological structure of the country ends. Rocks of Silurian, Devonian, or Carboniferous age have been proved at various points under the east of England - at Harwich, Ware, Turnford, Tottenham Court Road ; rocks of probably Triassic age have been found at Crossness and Richmond. Still further west and north-west the older rocks have been proved at Burford and Northampton. Over Central England the Jurassic and Triassic rocks cover a wide area, but from beneath these the older rocks appear in numerous places.

One of the most interesting questions connected with the recent earthquake is to ascertain whether there be any relation between the known range of these older rocks and the range of the earthquake over areas far distant from its central spot. At first it seemed certain that such was the case. The shock was plainly felt at Bristol, Wolverhampton, Birmingham, and Leicester-all places on or near to the outcrop of the older rocks. Numerous intermediate localities have since been mentioned, many not being connected, so far as we yet know, with the near existence of older rocks; but the far distant places still make it probable that some such connection exists.

It seems therefore likely that the wider and more general range of the earthquake is connected with the range of the Palæozoic rocks, whereas the local phenomena depend very largely upon the nature and thickness of the Secondary and Tertiary rocks. It is therefore important that those who study in detail the effects of the earthquake on the spot should do so with the aid of the Geological Survey Map of the district, which was surveyed by Mr. W. H. Dalton. The map and explanatory memoir are both published; in them the nature of the drift deposits are fully explained.

Almost all earthquakes have a very striking effect on springs and wells, sometimes causing a permanent change, at other times having merely a temporary influence. It is somewhat remarkable that so little has been recorded upon this point. A strong spring at West Mersea, which issues at the base of the Glacial gravel, where this bed rests upon London Clay, is said to have ceased to flow for a short time, and to have been discoloured when the water returned. Any residents in the district who have the opportunity of inquiring into similar cases, which doubtless occurred, will do good service by noting the facts.

Dr. J. E. Taylor's letter, which appears elsewhere, contains much valuable information, such as might well be collected from neighbouring areas; his observations as to the twisting of chimneys, \&c., and as to the direction in which that twist occurred, is a case in point. 